\title{
EKSEKUSI MATI DI INDONESIA (Perspektif Teori Hudud Muhammad Syahrur)
}

\author{
Hannani \\ Sekolah Tinggi Agama Islam Negeri (STAIN) Parepare \\ Email: hannani@stainparepare.ac.id
}

\begin{abstract}
This paper will examine the execution of death in Indonesia with the view of Hudud Muhammad Syahrur Theory. The execution of the death penalty imposed by the Indonesian government on the law's injunction against death row inmates involved in serious crimes such as terrorist leader, narcotics producer. Death penalty is not enough to be seen from a positive-conceptual perspective, but it must go through a case-by-case approach, as each case has its own context and uniqueness. The death penalty to be the maximum sentence in the hudud theory of Muhammad Syahrur is called all-haddul a'la, and a minimum of one year's imprisonment as a minimum limit by Muhammad Syahrur is called al-haddul adnaa.
\end{abstract}

Abstrak: Tulisan ini akan mengkaji tentang eksekusi mati di Indonesia dengan ditinjau dari Teori Hudud Muhammad Syahrur. Eksekusi hukuman mati yang diterapkan pemerintah Indonesia atas perintah Undang-Undang terhadap terpidana mati yang terlibat dalam kejahatan berat seperti gembong teroris, produsen narkotika. Pidana mati tidak cukup hanya dilihat dari perspektif positif-konseptual semata, namun harus lewat pendekatan kasus per kasus, dikarenakan masing-masing kasus memiliki konteks dan keunikannya sendiri. Hukuman mati menjadi hukuman maksimal dalam teori hudud Muhammad Syahrur disebut all-haddul a'la, dan minimal penjara selama satu tahun sebagai batas minimal oleh Muhammad Syahrur disebut dengan al-haddul adnaa.

Kata Kunci: Pidana, Hudud dan Eksekusi Mati

\section{PENDAHULUAN}

Keberadaan hukum diperlukan sebagai upaya melaksanakan ketertiban dalam masyarakat luas dengan berbagai kepentingannya, dan untuk menegakkan hak dan kewajiban dikenal adanya batasan dan batasan itu adalah hukum. Hukum dipandang bersifat ideal atau etis, hingga pengertian hukum tidak selalu sama dan terus berubah bersama berjalannya waktu dan sesuai tuntutan kebutuhan masyarakat dari jaman ke jaman.

Eksekusi hukuman mati yang diterapkan pemerintah Indonesia atas perintah Undang-Undang terhadap terpidana mati yang terlibat dalam kejahatan berat seperti gembong teroris, produsen narkotika yang menjadi hot issue di media massa baik media mainstream dan media on line, menjadi polemik pakar hukum di Indonesia. 
Ketegasan Presiden Joko Widodo dalam penegakan hukum mendapat apresiasi yang beragam. Persfektif ilmu hukum, sikap tersebut adalah bentuk keseriusan kepala negara dalam mengemban penegakan hukum dalam ruang sebuah negara berdaulat, sikap tersebut layak mendapatkan apresiasi positif dan meningkatkan citra Negara Indonsia sebagai Negara Hukum.

Diskursus eksekusi mati di Indonesia menjadi fokus dalam tulisan ini dengan topik eksekusi mati di Indonesia ditinjau dari Teori Hudud Muhammad Syahrur.

\section{PEMBAHASAN}

A. Hukuman Mati dalam Perundang - Undangan di Indonesia.

Hukuman mati (death penalty) di Indonesia memiliki dasar hukum yang kuat untuk melaksanakannya. Penolakan Mahkamah Konstitusi terhadap permohonan terpidana mati Keputusan Mahkamah Konstitusi (MK), Selasa (30/10), yang menolak uji materi hukuman mati yang terdapat dalam Undang-Undang Nomor 22 tahun 1997 memupuskan harapan para pengaju uji materi itu untuk lepas dari hukuman maksimal dalam kasus narkotika dan bahan berbahaya (narkoba). Jauh hari sebelumnya, sebanyak lima orang terpidana mati kasus narkotika mengajukan uji materi ke MK bertujuan menghapus hukuman mati yang termuat dalam UU Nomor 22/1997. Mereka adalah Edith Yunita Sianturi dan Rani Andriani yang Warga Negara Indonesia (WNI), serta tiga warga negara
Australia, Myuran Sukumaran, Andrew Chan, dan Scott Anthony Rush Edith, Rani, Sukumaran, dan Chan dalam persidangan di MK diwakili pengacara Todung Mulya Lubis, sedangkan Rush diwakili pengacara Denny Kailimang. Edith terlibat kasus peredaran heroin seberat seribu gram, sedangkan Rani dihukum dalam kasus peredaran heroin seberat 3.500 gram. Mereka divonis mati oleh Pengadilan Negeri (PN) Tangerang Ketiga WN Australia itu divonis mati oleh PN Denpasar, karena terbukti menyelundupkan sebanyak 8,2 kilogram heroin dari Australia ke Bali.

Mereka mengajukan uji materi terhadap pasal 80 ayat 1 huruf a, pasal 80 ayat 2 huruf a, pasal 80 ayat 3 huruf a, pasal 81 ayat 3 huruf a, pasal 82 ayat 1 huruf a, pasal 82 ayat 2 huruf a, dan pasal 82 ayat 3 huruf a yang tedapat dalam UU No 22 tahun 1997 Tentang Narkotika. Pasal-pasal itu mengatur tentang ancaman hukuman mati bagi produsen dan pengedar narkotika secara terorganisir. Namun, hanya permohonan Edith dan Rani yang diuji MK, sedangkan permohonan ketiga orang Australia tidak diuji karena sebagai orang asing mereka tidak berhak mengajukan uji materi UU ke MK. Setelah menguji materi tersebut, MK menyatakan keyakinannya bahwa hukuman mati bagi para produsen dan pengedar narkotika tetap sah, sehingga upaya lima terpidana mati kasus narkotika untuk menghapus hukuman mati pun sirna. Pidana mati, menurut MK, tidak bertentangan dengan hak untuk hidup yang dijamin oleh UUD 
1945, karena konstitusi Indonesia tidak menganut azas kemutlakan Hak Asasi Manusia (HAM). Dengan menerapkan pidana mati untuk kejahatan serius seperti narkotika, MK berpendapat, Indonesia tidak melanggar perjanjian internasional apa pun, termasuk Konvensi Internasional Hak Sipil dan Politik (ICCPR) yang menganjurkan penghapusan hukuman mati. Menurut MK, bahkan pasal 6 ayat 2 ICCPR membolehkan masih diberlakukannya hukuman mati kepada negara peserta, khusus untuk kejahatan yang paling serius. Sebaliknya, MK menyatakan, Indonesia memiliki kewajiban untuk mematuhi konvensi internasional tentang narkotika dan psikotropika yang telah diratifikasi oleh Indonesia dalam bentuk UU Narkotika. Konvensi itu justru mengamanatkan kepada negara pesertanya untuk memaksimalkan penegakan hukum secara efektif terhadap pelaku kejahatan narkotika. Konvensi tersebut juga mengamanatkan negara peserta untuk mencegah serta memberantas kejahatan-kejahatan narkotika yang dinilai sebagai kejahatan sangat serius, terlebih lagi yang melibatkan jaringan internasional. "Dengan demikian, penerapan pidana mati dalam UU Narkotika bukan saja tidak bertentangan UUD 1945, tetapi justru dibenarkan oleh konvensi internasional," kata Hakim Konstitusi Hardjono. ${ }^{1}$

Jenis hukuman yang paling banyak menimbulkan perdebatan adalah pemidanaan mati. Beberapa negara maju yang telah menghapus hukuman mati pun, masih juga menerapkan hukuman mati terhadap delik-delik tertentu. Meski sudah menjadi wacana klasik, pro-kontra seputar penerapan hukuman mati tetap menjadi perdebatan serius di kalangan masyarakat dunia. termasuk di Indonesia. Walaupun secara global menolak hukuman mati, tetapi pelaksanaan hukuman mati justru masih diterapkan di Indonesia. ${ }^{2}$ Indonesia memimpin penyampaian posisinya bersama sejumlah Like-Minded Countries / LMCs (Negara-Negara Sepaham, red) pada pembukaan the United Nations General Assembly Special Session/UNGASS (Sesi Khusus Sidang Umum PBB mengenai Masalah Narkoba Dunia) di Markas PBB New York, Selasa (19 April 2016) waktu setempat. Negara-negara LMCs yang satu posisi dengan Indonesia yakni RRT, Singapura, Malaysia, Brunei Darussalam, Uni Emirat Arab, Qatar, Pakistan, Mesir, Saudi Arabia, Yaman, Oman, Kuwait, Bahrain, Iran, dan Sudan. $^{3}$

KontraS dalam working paper berjudul "Praktik Hukuman Mati di Indonesia", yang memaparkan tabel data para terpidana mati yang sudah dieksekusi mati sejak 1979 hingga 2007. Selama kurun waktu itu, setidaknya 56 terpidana mati sudah dieksekusi di negeri ini. Kemudian bila ditambah jumlah terpidana mati yang sudah dieksekusi sejak 2008 hingga 2015, maka total keseluruhan sekitar 71 terpidana mati sudah dieksekusi. Dalam catatan KontraS ada tiga orang yang dieksekusi pertama kali, yakni Oesin 
Bestari pada 1979, kemudian Kusni Kasdud pada 1980 disusul Hengky Tupanwael pada tahun yang sama. Ketiganya merupakan terpidana mati kasus pembunuhan dengan korban lebih dari satu orang. 4

Ada fenomena menarik sepanjang tahun 2015 tentang ditemukannya lonjakan jumlah orang meninggal dunia akibat jumlah eksekusi mati di dunia. Hal itu terungkap berdasarkan laporan Amnesty International. Laporan tersebut menunjukkan bahwa tahun lalu jumlah orang yang meninggal oleh negara jadi yang terbanyak sejak 1989 .

Amnesty International setidaknya mencatat sebanyak 1.634 orang, secara resmi dihukum mati sepanjang 2015. Diperkirakan ribuan orang meninggal di Cina, namun catatannya disimpan untuk tetap menjadi rahasia. ${ }^{5}$

Secara yuridis formal, penerapan hukuman mati di Indonesia memang dibenarkan. Hal ini bisa ditelusuri dari beberapa pasal yang ada di dalam Kitab Undang-undang Hukum Pidana (KUHP). Selain itu, hukuman mati juga terdapat di dalam undang-undang di luar KUHP, misalnya Undang-Undang Teroris, Korupsi, Pencucian Uang dan masih banyak lagi. Hal ini menunjukkan bahwa hukuman mati di Indonesia semakin eksis dalam sistem hukum pidana di Indonesia. ${ }^{6}$

Salah satu kebijakan yang penting dalam mempertahankan hukuman mati dalam sistem hukum pidana Indonesia adalah terlihat dari pernyataan Presiden Republik Indonesia menegaskan bahwa tidak akan memberikan grasi terhadap para terpidana mati tindak pidana narkoba. ${ }^{7}$ Beliau mengatakan "Saya akan tolak permohonan grasi yang diajukan oleh 64 terpidana mati kasus narkoba. Saat ini permohonannya sebagian sudah ada di meja saya dan sebagian masih berputar-putar di lingkungan Istana," kata Presiden Jokowi. Presiden Jokowi menegaskan, kesalahan itu sulit untuk dimaafkan karena mereka umumnya adalah para bandar besar yang demi keuntungan pribadi dan kelompoknya telah merusak masa depan generasi penerus bangsa.

Namun, eksistensi hukuman mati tersebut tidak serta merta disetujui oleh seluruh kelompok masyarakat di Indonesia. Ada yang beranggapan bahwa hukuman mati bertentangan dengan konstitusi yang ada. Bahkan, untuk pertama kalinya permasalahan hukuman mati diajukan di hadapan Mahkamah Konstitusi (MK), karena dianggap bertentangan dengan Undang-Undang Dasar 1945, yaitu bertentangan dengan hak hidup yang dijamin berdasarkan Pasal 28I ayat (1) UUD $1945 .{ }^{8}$ Secara umum, para aktivis atau pegiat Hak Asasi Manusia (HAM) di Indonesia menolak pemberlakuan hukuman mati. Bahkan Komisi Nasional Hak Asasi Manusia (Komnas HAM) juga berpandangan bahwa hukuman mati tidak layak diterapkan di Indonesia. Apabila dikaitkan dengan pemberantasan suatu kejahatan maka tidak ada suatu jaminan dengan menerapkan hukuman mati akan mengurangi suatu kejahatan. Keteguhan sikap pemerintah Indonesia mempertahankan hukuman mati senada 
dengan aturan yang diterapkan dalam hukum pidana Islam, di mana terhadap delik-delik tertentu seperti tindak pidana zina muhshan, pembunuhan sengaja, perampokan dan dijatuhi dengan hukuman mati. Masyarakat Indonesia yang dominan beragama Islam, hukuman mati bukanlah hal yang baru bagi masyarakat Indonesia. Namun perbedaan pendapat terhadap hukuman mati di dalam hukum pidana Indonesia adalah terletak pada jenis-jenis kejahatan dan pelaksanaan hukuman mati. Pada prinsipnya, yang terpenting adalah kedua sitem ini mengakui eksistensi hukuman mati dan ini tidak ada perdebatan sama sekali karena secara tegas telah diatur oleh kedua sistem hukum ini. Namun, seiring dengan maraknya gagasan humanisme atau nilai-nilai kemanusiaan universal yang merebak seusai perang dunia kedua, hukuman mati dianggap tidak logis dalam kehidupan modern.10 Dengan kata lain, menurut para pembela HAM, dinamisasi hukum pidana di dunia saat ini telah bergeser dari teori pembalasan ke teori rehabilitasi, di mana teori tersebut bersifat clinic treatment. ${ }^{9}$

$$
\text { Pada akhirnya, muncullah }
$$
perdebatan di kalangan masyarakat seputar perlu tidaknya penerapan hukuman mati di Indonesia saat ini. ${ }^{10}$ Alih-alih menemukan titik temu atau kesepahaman, perdebatan seputar hukuman mati, justru semakin meruncing. Kedua aliran yang mendukung dan menolak hukuman mati kian kukuh dengan argumennya masingmasing, bahkan cenderung ekstrem, sehingga melupakan kaidah-kaidah ilmiah dan ilmu pengetahuan.

\section{B. Hukuman Mati dalam Hukum Pidana Islam}

Dalam istilah bahasa Arab hukuman dikenal dengan kata عقوبة _ _ ('uqûbah) yang berarti siksa atau hukuman, yaitu hukuman atas perbuatan yang melanggar ketentuan Syar'i yang ditetapkan untuk kemaslahatan masyarakat. Menurut 'Abd al-Qadîr 'Audah hukuman adalah pembalasan yang ditetapkan untuk kemaslahatan masyarakat, karena adanya pelanggaranpelanggaran atas ketentuan syara': Syaikh Wahbah Zuhailî membagi hukuman dalam Islam menjadi dua bentuk, yaitu:

Hukuman akhirat (al-'uqûbah alukhrawiyah) dan hukuman dunia (al'uquibah al-dunyawiyah). Hukuman akhirat merupakan kehendak Allah swt., adalah hukuman yang benar (haqq) dan adil (' $a d l$ ). Ia dapat berbentuk azab atau ampunan dari-Nya. Adapun hukuman dunia menurutnya ada dua macam pula, yaitu hudûd dan ta'zîr. ${ }^{11}$ Dalam hukum pidana Islam, hukuman mati merupakan bentuk hukuman maksimal yang memiliki dasar hukum yang kuat. ${ }^{12}$ Ini menunjukkan bahwa hukum Islam masih mempertahankan hukuman mati untuk tindak kejahatan tertentu, di mana esensi penerapannya bertujuan untuk melindungi kepentingan individu dan masyarakat dari tindak kejahatan yang membahayakan sendi-sendi dasar kemanusiaan. ${ }^{13}$ Dalam hukum Islam, hukuman mati bisa ditemukan dalam tiga 
bentuk pemidanaan, yaitu qishâsh, hudûd dan ta'zîr. Dalam masalah qishâsh, ancaman hukuman mati ditujukan bagi pelaku pembunuhan yang disengaja atau direncanakan. ${ }^{14}$ Dalam masalah hudûd, ancaman hukuman mati ditujukan bagi pelaku zina muhshan, hirâbah, al-baghyu, dan riddah. Sedangkan dalam masalah ta'zîr, ancaman hukuman mati ditujukan bagi pelaku kejahatan di luar qishâsh dan hudûd yang oleh negara (penguasa) dianggap sangat berbahaya bagi kelangsungan hidup dan kemaslahatan masyarakat.

Hukuman mati yang diberlakukan untuk kasus-kasus tertentu, semisal narkoba, terorisme dan korupsi, termasuk kategori hukuman ta 'zîr yang disebut dengan 'al-qatlu al-siyasi', yaitu hukuman mati yang tidak diatur oleh alQur'an dan Sunnah, tapi diserahkan kepada negara, baik pelaksanaan ataupun tatacara eksekusinya. Hukuman mati tersebut boleh diberlakukan oleh suatu negara jika dipandang sebagai upaya efektif menjaga ketertiban dan kemaslahatan masyarakat. ${ }^{15}$

Adanya ancaman hukuman mati dalam Islam, menurut Barda Nawawi Arief, pada hakikatnya bukanlah sarana utama untuk mengatur, menertibkan, atau melindungi masyarakat, tetapi lebih merupakan jalan hukum terakhir, seperti halnya amputasi dalam kedokteran yang sebenarnya bukan obat utama, tetapi sebuah pengecualian sebagai sarana pengobatan terakhir. ${ }^{16}$ Dengan demikian, ada kriteria-kriteria tertentu yang diatur dalam hukum Islam yang memungkinkan suatu tindak kejahatan tersebut dapat dijatuhi hukuman mati. ${ }^{17}$

Munculnya perdebatan tentang hukuman mati sebagaimana telah dijelaskan pada akhirnya melahirkan setidaknya dua kelompok besar, yaitu kelompok yang ingin menghapus hukuman mati dan kelompok yang mendukung penerapan hukuman mati. Bagi kalangan yang menolak, hukuman mati merupakan bentuk pembunuhan yang dilegalkan oleh negara dan hal ini melanggar hak asasi manusia, karena hak hidup adalah hak dasar yang tidak bisa dikurangi dengan alasan apa pun (non-derogable rights) oleh individu. Sedangkan kelompok yang mendukung, hukuman mati adalah satu bentuk hukuman yang masih dibutuhkan untuk membuat efek cegah dan mengurangi kejahatan-kejahatan yang tergolong besar atau luar biasa di tengah masyarakat.

Menurut Suhaidi, Guru Besar pada Fakultas Hukum Universitas Sumatera Utara bahwa hukuman mati perlu diterapkan terhadap pelaku kejahatan berat seperti pembunuhan secara sadis dan bandar narkoba. Tujuannya adalah untuk membuat efek jera, sehingga masyarakat merasa takut melakukan perbuatan salah dan melanggar hukum. Jadi penerapan hukuman mati itu janganlah dianggap sebagai suatu balas dendam atau pelanggaran HAM terhadap pelaku kejahatan. Penilaian seperti ini tidak dapat diterima, apalagi dikaitkaitkan pula bahwa tindakan itu tidak manusiawi. $^{18}$ 
Hudîd adalah hukuman-hukuman yang telah ditentukan bentuknya oleh Syar'i dengan nash-nash yang jelas. Hukuman hâdd menurut Hanafiyah ada lima macam yaitu, hâdd zina, hâdd qadzf, hâdd pencurian, hâdd minum khamr, dan hâdd mabuk. Sedangkan menurut jumhur ulama selain Hanafiyah ada tujuh macam yaitu hâdd zina, hâdd qadzf, hâdd pencurian, hâdd hirâbah, hâdd mabuk-mabukan, hâdd qishâsh, dan hâdd riddah. ${ }^{19}$

Ta'zîr adalah hukuman yang tidak ditentukan oleh syara', tetapi bentuk dan ketentuannya diserahkan kepada wali alamr (negara) dengan memperhatikan perbedaan waktu dan tempat. Hukuman mati merupakan salah satu alternatif hukuman yang diberikan kepada para pelaku tindak pidana hudûd. Namun demikian hukuman mati hanya diberikan kepada empat pelaku hudûd, yaitu: zin muhsan, pembunuh sengaja, perampokan (al-hirabah), dan murtad.

\section{Teori Hudud Muhammad Syahrur}

Nama lengkap dari pemikir Islam liberal ini adalah Muhammad Syahrur Ibnu Dayb. Ia dilahirkan di Perempatan Salihiyah, Damaskus, Syria pada tanggal 11 April 1938. Syria merupakan salah satu negara yang pernah mengalami problem modernitas khususnya benturan keagamaan dengan gerakan modernisasi barat.

Sebuah teori mengatakan bahwa setiap kegiatan intelektual yang memancar dari suatu kegelisahan tidak dapat dipisahkan dari problematika sosial yang melingkupinya. Dengan kata lain, sebuah konstruk pemikiran yang muncul memiliki relasi signifikan dengan realitas sosial sebagai respon dan dialektika pemikiran dengan berbagai fenomena yang berkembang di masyarakat. $^{20}$ Syahrur, dalam mengkonstruk pemikirannya, khususnya yang terkait dengan keislaman, tidak lepas dari teori ini. Ide-idenya muncul setelah secara sadar mengamati perkembangan dalam tradisi ilmu-ilmu keislaman kontemporer.

Syahrur menawarkan berbagai teori inovatif dan revolusioner dalam hukum Islam dan salah satu diantaranya adalah tentang Teori Hudud (teori batas-batas hukum) atau Teori Limit. Teori hudūd atau teori batas dapat digambarkan sebagai perintah Allah yang diungkapkan dalam al-Qur'an dan Sunah mengandung ketentuan-ketentuan yang merupakan batas terendah (al-had aladnaa) dan batas tertinggi (al-had ala'laa) untuk seluruh perbuatan manusia. $^{21}$ yang dimaksud teori limit atau hudud adalah sebuah metode memahami ayat-ayat hukum (muhkamat) sesuai dengan konteks sosio-historis masyarakat kontemporer agar ajaran alQur'an tetap relevan dan kontekstual sepanjang masih berada dalam wilayah batas hukum Allah. Buah dari penelitian yang diakuinya tersebut, lahirlah sebuah teori yang aplikatif, yakni nazhariyyah al-hudud (limit theory/teori batas). Teori batasnya terdiri dari batas bawah (alhadd aladnal minimal) dan batas atas (al-hadd al-a'la/maksimal). 
Kontribusi $\begin{array}{r}\text { dari } \\ \text { teori }\end{array}$ ini
sebagaimana dikutip dari buku
Epistemologi
Tafsir
pertama, dengan teori limit, ayat-ayat
hukum yang selama ini dianggap final
dan pasti tanpa ada alternatif
pemahaman lain ternyata memiliki
kemungkinan untuk diinterpretasikan
secara baru dan Syahrur mampu menjelaskannya secara metodologis dan mengaplikasikannya dalam penafsirannya melalui pendekatan matematis. Kedua, dengan teori limit, seorang mufassir akan mampu menjaga sakralitas teks tanpa harus kehilangan kreatifitasnya dalam melakukan ijtihad untuk membuka kemungkinan interpretasi sepanjang masih berada dalam batas-batas hukum Allah. ${ }^{22}$ Dalam kasus hukum ketetapan terendah adalah batasan minimum dan tertinggi adalah batasan maksimum. Tidak ada bentuk hukum yang lebih rendah dari batas minimum dan lebih tinggi dari batas maksimum. Hukum akan ditetapkan antara batas maksimum dan minimum tergantung dari kualitas kesalahan yang dilakukan. Dan ketika batas-batas ini dijadikan panduan, kepastian hukum akan terjamin sesuai dengan ukuran kesalahan yang dilakukan. Artinya ketika batas-batas dilampaui, maka hukuman harus dijatuhkan menurut proporsi pelanggaran yang terjadi. Jadi manusia dapat melakukan gerak dinamis di dalam batas-batas yang telah ditentukan.

Batas Tuhan (hudud Allah), oleh Syahrur diibaratkan sebagai garis-garis lurus dan konstan (ats-tsawabit), sementara pada saat yang sama memberi ruang pada manusia untuk bergerak dinamis (at-taghayyur) dalam hukum. ${ }^{23}$ Dengan kata lain, batas-batas itu merupakan representasi dari kekokohan hukum yang tak lekang oleh panas dan tak lapuk oleh hujan. Sementara ruang yang diberikan itu merepresentasikan sisi fleksibilitas hukum Islam yang selalu dinamis dan selaras dengan tuntutan zaman. Perpaduan antara sesuatu yang konstan dan tsawabit inilah yang kemudian dirumuskan oleh Syahrur sebagai hakikat hukum Islam. Dalam prakteknya, ia menetapkan enam prinsip batas, yang dibentuk dari perpaduan antara sumbu Y (Hudud Allah) dan sumbu $\mathrm{X}$ (realitas historis manusia). Keenam teori batas yang dicetuskannya itu tak lain, juga sebagai bentuk negosiasi terhadap hudud Tuhan. Enam teori tersebut adalah:

1. Batas minimal (al-hadd al-adnā)

Menurut Syahrur, Allah telah memberikan kepada manusia batasbatas minimal. Batas minimal ini tak boleh dilampaui agar menjadi lebih minimal lagi. Batas minimal adalah batas terendah yang diberikan oleh Allah tentang sesuatu yang boleh dilakukan. Di antara batas minimal yang telah ditetapkan Allah adalah batas minimal dalam hal keharaman menikahi perempuan. Perempuanperempuan yang haram dinikahi tersebut dijelaskan dalam an-Nisa' (4): 22-23. Selain itu, ayat lain yang menjelaskan tentang batas minimal adalah ayat yang menjelaskan 
persoalan pakaian perempuan yang terkandung dalam an-Nur (24): $31 .^{24}$ Pada batas minimal ini seolah tak ada negosiasi hudud, namun sebenarnya, negosiasi hudud dalam hal ini masih tetap ada. Jika dicermati, konsep batas minimal tawaran Syahrur ini berusaha memberikan peluang pada seseorang untuk bernegosiasi dengan menambah apa yang telah ditetapkan Tuhan, tentu dengan berbagai pertimbangan dan dalam kondisi tertentu, seperti yang terjadi pada kasus perempuan yang haram dinikahi dan persoalan pakaian perempuan di atas.

2. Batas maksimal (al-hadd al-a'lā)

Sebagaimana ada batas minimal, maka sangat wajar bila Syahrur pun menetapkan bahwa dalam kandungan Ummul $\mathrm{Kitab}^{25}$ terdapat juga batas maksimal. Ia mencontohkan batas maksimal ini dengan ayat yang menjelaskan tentang hukuman potong tangan bagi pencuri, yaitu pada surat alMaidah (5): $38 .{ }^{26}$ Berdasar ayat tersebut Syahrur berkesimpulan bahwa seorang pencuri tidak boleh dihukum melebihi potong tangan, sebab yang demikian itu adalah batas maksimal yang telah ditetapkan Tuhan. Sebaliknya, seorang hakim boleh menetapkan hukuman yang lebih ringan dari potong tangan yang tentunya dengan memperhatikan situasi dan kondisi tertentu. Tawaran batas maksimal yang ditetapkan Syahrur ini sesungguhnya, telah dilakukan oleh sahabat Umar ibn Khatthab yang tidak menghukum potong tangan pada seorang pencuri lantaran pada saat itu adalah musim paceklik. Dari sini kemudian langkah yang diambil oleh Umar yangbelakangan diadopsi dan dijadikan sebagai salah satu konsep istinbath hukum oleh Syahrur ini bisa disebut sebagai bentuk negosiasi terhadap Hudud Tuhan.

3. Batas maksimal dan minimal yang datang secara bersamaan, namun tidak menyatu dalam satu garis (alhadd al-adnā wa al-hadd al-a'lā ma'an)

Dalam pandangan Syahrur, salah satu ayat yang mempunyai batasan minimal dan maksimal sekaligus adalah ayat yang menjelaskan tentang warisan, yaitu surat an-Nisa' (4): 11, 12, 13 dan 14). Terkait dengan ayat waris ini, Syahrur berpandangan bahwa tujuan utama disyariatkannya pembagian waris adalah semata-mata demi keadilan, baik pada ahli waris perempuan maupun ahli waris lakilaki, karena itu untuk bisa menemukan keadilan itu harus menggunakan prinsip himpunan dan pendekatan matematika modern. Menurutnya, aturan dua banding satu bagi ahli waris laki-laki dan perempuan berlaku saat pihak perempuan tak ikut menanggung beban ekonomi keluarga. Apabila perempuan ikut menanggung beban ekonomi keluarga, maka 
kesenjangan bagian itu semakin kecil sesuai dengan tingkat kerja sama dalam menanggung beban ekonomi yang bersangkutan. Dalam hal ini, seorang mujtahid bertugas menentukan bagian masing-masing pihak sesuai dengan semangat persamaan dan keseimbangan bagian antara pihak laki-laki dan perempuan berdasar kondisi sosialhistoris-objektif yang dikuatkan dengan bukti-bukti materiil statistik serta dengan mempertimbangkan kemaslahatan dan kemudahan bagi masyarakat. $^{27}$

Selain itu, ayat yang mengandung batas minimal dan maksimal adalah ayat poligami, yaitu surat an-Nisa' (4): 3. Ayat ini dipandang Syahrur sebagai ayat hududiyah. Ia hadir untuk menggabungkan batas minimal dan maksimal dalam sebuah kuantitas dan kualitas sekaligus. Batas minimal kuantitasnya adalah menikahi satu orang perempuan dan batas maksimalnya adalah empat orang perempuan, dengan ketentuan kualitas bahwa istri kedua sampai dengan istri keempat adalah seorang janda yang cerai mati, bukan cerai talak. ${ }^{28}$ Dari kedua contoh ayat yang diberikan Syahrur di atas, terlihat jelas bahwa di sana ada hudud Tuhan yang amat fleksibel untuk dilakukan sebuah negosiasi.

4. Batas minimal dan maksimal yang menyatu dalam satu titik atau garis lurus (al-hadd al-adnā wa al-hadd al- a'lā 'ala nuqthatin wāhidatin ay hālat al-mustaqīm aw hālat attasyrī' al- 'ainiy)

Batas jenis keempat ini, menurut Syahrur hanya terdapat pada surat anNur (24): 2 yang menjelaskan tentang hukuman bagi seorang pezina. Satu titik tersebut dalah 100 jilid. Dalam hal ini 100 kali jilid dianggap sebagai batas minimal dengan alasan bahwa pada ayat sesudahnya Allah memberikan peringatan untuk tidak merasa belas kasihan pada pezina. Sedangkan terkait batas maksimalnya, Syahrur tidak secara tegas menjelaskan. Namun, Muhyar Fanani berkesimpulan bahwa alasan mengapa 100 kali jilid dianggap batas maksimal adalah karena sudah hampir dipastikan seorang tidak akan mampu lagi bertahan hidup setelah didera 100 kali. $^{29}$

Menurut Syahrur, inilah satusatunya tasyri' 'aini (tertentu dan pasti $)^{30}$, sehingga dalam hal ini tak ada peluang untuk melakukan penambahan atau pengurangan pada hukuman tersebut. Dengan demikian, pada batas ini tak ada tawar menawar maupun negosiasi.

5. Batas maksimal berupa garis yang mendekati garis lurus, namun tak sampai menyentuh (al-hadd al-a'lā bi khattin muqāribin li mustaqìmin ay yaqtaribu wa là yamassu)

Pada batas ini, Syahrur memberikan contoh hubungan lakilaki dan perempuan yang tidak sampai pada tahap zina yang terdapat pada surat al-Isra' (17): 32. Jenis batas kelima ini, menurutnya 
sangat terkait dengan jenis batas keempat sebelumnya. Dalam hal ini, seorang tidak diperkenankan mendekati zina, sebab batas maksimalnya adalah mendekati zina itu sendiri. ${ }^{31}$ Dengan demikian dalam batas ini -sebagaimana pada batas keempat- tak ada peluang untuk bernegosiasi. Hanya saja, persoalan ukuran mendekati zina ini tak bisa diputuskan secara pasti dan dipositivisasi. Persoalan tersebut amat relatif dan tergantung pada keputusan dan pertimbangan mujtahid. Karena itulah, boleh jadi peluang untuk sedikit berngosiasi ada pada penentuan mujtahid tersebut.

6. Batas maksimal positif-tertutup yang tak boleh dilampaui, sementara batas minimalnya negatif dan boleh dilampaui (al-hadd al-a'lā müjibun mughlaqun lā yajūzu tajāwuzuhu, wa al-hadd adnā sālibun yajūzu tajāwuzuhu)

Teori batas terakhir ini berlaku pada transaksi bendawi manusia. Syahrur mencontohkan bahwa dalam persoalan transaksi ini batas maksimalnya berupa riba dan batas minimalnya berupa zakat. Riba sama sekali tak boleh dilampaui sedangkan zakat sebagai batas minimal boleh dilampaui ke arah negatif dengan membayar sedekah. Di antara kedua batas tersebut terdapat posisi nol, yang terwujud dalam bentuk transaksi al-qardl alhasan (pinjaman tanpa bunga). ${ }^{32}$

\section{Eksekusi Mati dalam Perspektif Teori Hudud Muhammad Syahrur}

Hukuman mati menjadi salah satu ganjaran atau hukuman yang telah diterapkan di Indonesia. Pelaksanaan pidana mati di Indonesia menjadi bahan pembicaraan yang cukup aktual dan polemik yang berkepanjangan. Penerapan pidana mati bertentangan dengan falsafah negara yang menganut faham pancasila, yang selalu menjunjung tinggi rasa perikemanuisaan yang adil dan beradab. Namun demikian dalam kenyataannya, penerapan pidana mati apapun alasan dan logikanya tetap dilaksanakan di Indonesia dari berbagai kasus tindak pidana yang ada. ${ }^{33}$ Timbulnya kontroversi mengenai pidana mati juga diperdebatkan akibat adanya amandemen kedua pasal 28 A dan pasal 28 ayat 1 UUD 1945 yang secara tegas menyatakan. Setiap orang berhak mempertahankan hidup dan kehidupannya, sehingga semua produk hukum yang masih mencamtunmkan pidana mati sebagai ancaman pidana harus diubah atau dibenahi.

Penerapan hukuman mati di Indonesia merupakan batas maksimal atau al-Haddul a'la menurut Muhammad Syahrur dalam teori hududnya seperti ancaman hukuman bagi pelaku teroris, bandar narkoba, makar, dan pembunuhan berencana. Penerapan pidana mati menimbulkan efek jera terhadap pelaku tapi juga sebagai suatu upaya untuk mencegah terjadinya tindak kriminal sebagai 
bentuk pembalasan terhadap kejahatan yang penerapannya harus dilakukan seselektif mungkin.

Pidana mati sebagai hukuman terberat yang dijatuhkan atas seseorang akibat perbuatannya menjadi alternatif terakhir untuk mengayomi masyarakat. Penetapan hukuman mati bagi seorang hakim tidak saja hanya berpedoman pada undang-undang, namun hakim juga mempunyai pertimbangan-pertimbangan lain karena seorang hakim memiliki kebebasan mandiri untuk menentukan putusannya. Selain kebebasan mandiri, seorang hakim memiliki kebebasan mutlak dan tidak dicampuri oleh pihak lain. Hal ini disebabkan untuk menjamin agar putusan pengadilan benar-benar obyektif serta kebebasan yang dimiliki harus berdasarkan rasa keadilan baik terhadap terdakwa maupun masyarakat dan bertanggung jawab terhadap Allah swt. Penetapan hakim yang menetapkan hukum yang lebih ringan dalam teori hudud Muhammad Syahrur dikenal dengan al-Haddul adna sebagai batas minimal atau membebaskannya apabila tidak terbukti secara meyakinkan melakukan pelanggaran.

Putusan hukuman mati dimasa yang akan dating menurut keputusan Mahkamah Konstitusi No. 2-3/ PUUV/2007 hendaknya memperhatikan empat hal penting. Pertama, pidana mati bukan lagi merupakan pidana pokok, melainkan sebagai pidana bersifat khusus dan alternative, kedua, pidana mati dapat dijatuhkan dengan masa percobaan selama sepuluh tahun apabila terpidana mati berkelakuan terpuji dapat diubah dengan pidana penjara seumur hidup atau selama 20 tahun, ketiga, pidana mati tidak dapat dijatuhkan pada anak-anak yang belum dewasa. Keempat, eksekusi pidana mati terhadap perempuan hamil dan seseorang yang sakit jika ditangguhkan sampai perempuan hamil tersebut melahirkan dan terpidana sakit sampai sembuh. ${ }^{34}$

Namun, pemerintah Indonesia meyakini hukuman mati bahwa jenis hukuman ini bisa mengurangi kejahatan. Seperti yang ditekankan oleh Presiden Joko Widodo, Hukuman mati diyakini menjadi cara efektif mengurangi dampak dan untuk mencegah terlibat dalam kriminal. Dalam hal ini, ada keyakinan bahwa lebih baik 'membunuh' segelintir manusia, demi menyelamatkan lebih banyak nyawa.

Memang, masalah ini tampaknya menjadi perbedaan utama antara mayoritas orang-orang yang menentang dan mendukung hukuman mati. Jadi, argumen mana yang lebih valid: argumen orang-orang yang menentang atau yang pro-hukuman mati. Untuk menentukan ini, kita harus melihat data, menganalisis, dan/atau membandingkan artikel akademis tentang hubungan antara hukuman mati dan efektivitasnya. Perbedaan pendapat harus diselesaikan melalui penelitian dan studi lebih lanjut, serta akal sehat.

\section{PENUTUP}

Berdasarkan uraian di atas, jelas bahwa eksekusi mati tetap dipertahankan dan dilaksanakan di Indonesia, beberapa di antaranya sudah 
dieksekusi. Terpidana mati adalah kasus pembunuhan, terorisme, penyalahgunaan narkotika berupa pengedar narkotika, meskipun dasar hukum yang kuat terhadap pidana mati tidak serta merta membuat pemerintah dengan mudah menghukum mati terpidana. Pidana mati tidak cukup hanya dilihat dari perspektif positif-konseptual semata, namun harus lewat pendekatan kasus per kasus, dikarenakan masing-masing kasus memiliki konteks dan keunikannya sendiri. Ancaman hukuman mati. Hukuman mati menjadi hukuman maksimal dalam teori hudud Muhammad Syahrur disebut all-haddul a'la, dan minimal penjara selama satu tahun sebagai batas minimal oleh Muhammad Syahrur disebut dengan al-haddul adnaa.

\section{Catatan Akhir :}

http://www.antaranews.com/print/82265/ke putusan-mk-pupuskan-harapan-terpidanahukuman-mati-kasus-narkoba di akses 10 Agustus 2016

${ }^{1}$ Andi Hamzah et al., Pidana Mati di Indonesia di Masa Lalu, Masa Kini dan Masa yangAkan Datang, cet. 2 (Jakarta: Ghalia Indonesia, 1985), h. 2.

${ }^{1}$ http://news.detik.com/berita/3192872/indo nesia-pimpin-negara-negara-tolak-hapushukuman-mati di akses 10 Agustus 2016

${ }^{1}$ http://www.merdeka.com/peristiwa/3penjahat-legendaris-ini-dieksekusi-mati-pertamakali-di-indonesia.html diakses pada hari, senin, 1 Agustus 2016

${ }^{1}$ https://serambimata.com/2016/04/07/indon esia-masuk-salah-satu-dari-10-negara-terbanyakeksekusi-hukuman-mati/ di akses 10 Agustus 2016

${ }^{1}$ http://www.legalitas.org/?q=content/dilem a-hukuman-mati. 10 Mei 2016.
${ }^{1}$ http://nasional.kompas.com/read/2014/12/1 0/07494911/Jokowi.Jangan.Tolak.Grasi.jika.Han ya.Ingin.Tunjukkan.Ketegasan

${ }^{1}$ Uji materil (judicial review) hukuman mati tersebut dilakukan terhadap beberapa terpidana mati yang melakukan tindak pidana narkotika berdasarkan Undang-Undang No. 22 Tahun 1997 Tentang Narkotika. Mereka beranggapan bahwa hukuman mati tersebut bertentangan dengan Undang-Undang Dasar 1945. Melalui uji materil inilah yang akan nantinya menilai apakah hukuman mati tersebut bersifat konstitusional ataupun tidak. Pan Mohamad Faiz, "Perdebatan Konstitusionalitas Hukuman Mati," dalam the Jakarta Post, 4 Mei 2007.

${ }^{1}$ Kompas, 10 Agustus 2016.

${ }^{1}$ J. E. Sahetapi, Suatu Studi Khusus Mengenai Ancaman Pidana Mati, h. 21

${ }^{1}$ Imam Yahya, "Hukuman Mati Perspektif Syari'ah," dalam http://imamyahya.blogspot.com/ 2009/04/hukuman-mati-perspektif-syariah.html. Selasa, 14 April 2009.

${ }^{1}$ QS. al-Baqarah/2: 179.

1،Abd al-Wahab al-Khalâf, Science Ushûl al-Fiqh (Kuwait: Dâr al-Qalam, 1992), h. 198; Lihat juga dalam buku Muhammad Abû Zahrah, Ushûl al-Fiqh (Kairo: Maktabah Muhaimar, 1957), h. 351.

'A Abd al-Qadir Audah, al-Tasyri' al-Islâmi Jina'iy: Muqâranah bi al-Qanûn al-Wadh 'i, JuzI (Beirut: al-Risâlah Mu'assasah, 1992), h. 663.

${ }^{1}$ Ibid.

1 Barda Nawawi Arief, Bunga Rampai Kebijakan Hukum Pidana (Bandung: Citra Aditya, 1996), h. 99.

${ }^{1}$ Zafrullah Khan Muhammad, Islam and Human Rights (Islamabad: Islam International Publications Ltd., 1988), h. 74.

${ }^{1} \mathrm{http} / / / \mathrm{www}$.antara.co.id/view/?i=11978250

$88 \& c=N A S \& s=.22$ September 2016.

${ }^{1}$ Ibid.

${ }^{1}$ Andreas Chrismann, Bentuk Teks (Wahyu) Tetap, Tetapi Kandungannya Selalu Berubah: Tekstualitas dan Penafsirannya dalam Al Kitab wa Al-Qur'an Pengantar dalam Syahrur, Metodologi Fiqh Islam Kontemporer, h. 19 
${ }^{1}$ Muhammad Syahrur, Prinsip dan Dasar Hermeneutika Hukum Islam Kontemporer, terj. Sahiron Syamsuddin, cet.I, h. 6-7

${ }^{1}$ Abdul Mustaqim, Epistemologi Tafsir Kontemporer, cet II (Yogyakarta: Lkis, 2012), h. 93.

${ }^{1}$ Muhammad Syahrur, al-Kitab wa alQur'an, qira'ah mu'ashirah, (Damaskus: alAhaliy, t.t.), h. 452 .

${ }^{1}$ Ibid., h. 456.

${ }^{1}$ Ummul Kitab adalah sebutan khas Syahrur untuk menunjuk pada ayat-ayat yang berisikan kumpulan hukum-hukum syari'at. Sedangkan term al-Qur'an dalam bahasa mayoritas ulama, disebutnya sebagai at-Tanzil al-Hakim. Perbedaan penggunaan istilah ini sebagai salah satu konsekwensi dari salah satu anggapannya yang tak setuju dengan konsep sinominitas bahasa. Pandangan seperti itu ia adopsi dari salah satu pakar linguistik bernama Ibnu al-Jinni yang merupakan murid dari al-Farisi, seorang pakar linguistik arab kontroversional. Terkait perbedaan-perbedaan istilah ini bisa dilihat pada Muhammad Syahrur, al-Kitab wa al-Qur'an, qira'ah mu'ashirah, (Damaskus: al-Ahaliy, t.t.). dan Muhammad Syahrur, Nahwa Ushul alJadidah li al-Fiqh al-Islami, (Damaskus: alAhaliy, 2000).

${ }^{1}$ Syahrur, op.cit., h. 456.

${ }^{1}$ Muhyar Fanani, Fiqh Madani, Konstruksi Hukum Islam di Dunia Modern, (Yogyakarta: KIS, 2010), h. 278. Lihat juga pada Muhammad Syahrur, Nahwa Ushul al-Jadidah li al-Fiqh alIslami, Damaskus: al-Ahaliy, 2000), h. 231.

${ }^{1}$ Ibid., h. 263.

${ }^{1}$ Ibid., h. 264.

${ }^{1}$ Muhammad Syahrur, al-Kitab wa alQur'an, qira'ah mu'ashirah, (Damaskus: alAhaliy, t.t.), h. 464.

${ }^{1} I b i d .$, h. 465.

${ }^{1}$ Ibid.,

${ }^{1}$ M. Zen Abdullah, Pelaksanaan Pidana Mati di Indonesia telaah dalam kontek Hak Asasi Manusia, Jurnal Ilmiah Universitas Jambi 2009, h. 61 .

${ }^{1}$ http://www.peraturan.go.id/putusanmk/putusan-mk- 11e58868579f58d88ccc313833353433.html diakses 10 Agustus 2016

\section{DAFTAR PUSTAKA}

Al-Quran al-Karim

'Abd al-Qadir Audah, al-Tasyri' alIslâmi Jina'iy: Muqâranah bi alQanûn al-Wadh ' $i$, JuzI, Beirut: alRisâlah Mu'assasah, 1992

'Abd al-Wahab al-Khalâf, Science Ushûl al-Fiqh, Kuwait: Dâr al-Qalam, 1992

Abdul Mustaqim, Epistemologi Tafsir Kontemporer, cet II, Yogyakarta: Lkis, 2012

Andi Hamzah et al., Pidana Mati di Indonesia di Masa Lalu, Masa Kini dan Masa yangAkan Datang, cet. 2 (Jakarta: Ghalia Indonesia, 1985)

Andreas Chrismann, Bentuk Teks (Wahyu) Tetap, Tetapi

Kandungannya Selalu Berubah: Tekstualitas dan Penafsirannya dalam Al Kitab wa Al-Qur'an Pengantar dalam Syahrur, Metodologi Fiqh Islam Kontemporer, 2005

Barda Nawawi Arief, Bunga Rampai Kebijakan Hukum Pidana, Bandung: Citra Aditya, 1996

J. E. Sahetapi, Suatu Studi Khusus Mengenai Ancaman Pidana Mati,

M. Zen Abdullah, Pelaksanaan Pidana Mati di Indonesia telaah dalam kontek Hak Asasi Manusia, Jurnal Ilmiah Universitas Jambi 2009 Muhammad Abû Zahrah, Ushûl al-Fiqh Kairo: Maktabah Muhaimar, 1957 
Muhammad Syahrur, al-Kitab wa alQur'an, qira'ah mu'ashirah, Damaskus: al-Ahaliy, t.t.

Muhammad Syahrur, Nahwa Ushul alJadidah li al-Fiqh al-Islami, Damaskus: al-Ahaliy, 2000.

Muhammad Syahrur, Prinsip dan Dasar Hermeneutika Hukum Islam Kontemporer, terj. Sahiron Syamsuddin, cet.I

Muhyar Fanani, Fiqh Madani, Konstruksi Hukum Islam di Dunia Modern, Yogyakarta: KIS, 2010

Pan Mohamad Faiz, "Perdebatan Konstitusionalitas Hukuman Mati," dalam the Jakarta Post, 4 Mei 2016. Zafrullah Khan Muhammad, Islam and Human Rights, Islamabad: Islam International Publications Ltd., 1988 http://nasional.kompas.com/read/2014/1

2/10/07494911/Jokowi.Jangan.Tola

k.Grasi.jika.Hanya.Ingin.Tunjukkan. Ketegasan http://news.detik.com/berita/3192872/in

donesia-pimpin-negara-negara-

tolak-hapus-hukuman-mati di akses

10 Agustus 2016

http://www.antara.co.id/view/?i=119782

$5088 \& \mathrm{c}=\mathrm{NAS} \& \mathrm{~s}=. \quad 22 \quad$ September 2016.

http://www.antaranews.com/print/82265/ keputusan-mk-pupuskanharapan-terpidana-hukumanmati-kasus-narkoba di akses 10 Agustus 2016

http://www.legalitas.org/?q=content/dile ma-hukuman-mati. 10 Mei 2016.

http://www.peraturan.go.id/putusan$\mathrm{mk} /$ putusan-mk11e58868579f58d88ccc3138333 53433.html diakses 10 Agustus 2016 https://serambimata.com/2016/04/07/ind onesia-masuk-salah-satu-dari-10negara-terbanyak-eksekusihukuman-mati/ di akses 10 Agustus 2016

Imam Yahya, "Hukuman Mati Perspektif Syari'ah," dalam http://imamyahya.blogspot.com/ 2009/04/hukuman-matiperspektif-syariah.html. 